\title{
Genetic Variability in Tomato (Lycopersicon esculentum MILL) Genotypes in the Central Rift Valley, Ethiopia
}

\section{Dasta Tsagaye ${ }^{1 \rtimes}$ \\ Andargachew Gadebo ${ }^{2}$ Shimelis Aklilu ${ }^{3}$}

'Kulumsa Agricultural Research Center, Horticulture Research Program, Assella, Ethiopia. Email:6dasta2@gmail.com Tel: +251917239564

'Shool of Plant and Horticultural Sciences, Hawassa University College of Agriculture Hawassa, Ethiopia. Email: andargacherwg@gmail.com Tel: +251935408619

${ }^{s}$ Melkassa Agricultural Research Center, Vegetable Breeding Program, Adema, Ethiopia.

Email:shimiakl@yahoo.com Tel:+251911756168

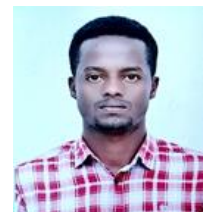

Corresponding Author)

\begin{abstract}
Investigation of variability existing in crop cultivars is important to crop improvement. The study was conducted at Melkassa Agricultural Research Center (MARC) to assess the genetic variability among 36 tomato genotypes using $6^{*} 6$ simple lattice designs. There were significant differences among genotypes all traits. High phenotypic and genotypic variances were recorded for number of fruits per plant, average fruit weight, fruit shape index and juice volume indicating the existence of substantial variability. High heritability along with high genetic advance as percent of the mean was exhibited by characters viz. plant height, number of fruits per plant, average fruit weight, fruit shape index and juice volume, reflecting the presence of additive gene action for the expression of these traits and selection based on them would be ideal. Generally, the present study implied the presence of genetic variability among the test genotypes with respect to the traits considered indicating an opportunity to bring about fruit yield improvements in snap bean either through direct selection or hybridization.
\end{abstract}

Keywords: Tomato, Genotype, GCV, PCV, Genetic advance, Genetic variability, Heritability.

Citation | Dasta Tsagaye; Andargachew Gadebo; Shimelis Aklilu (2020). Genetic Variability in Tomato (Lycopersicon esculentum MILL) Genotypes in the Central Rift Valley, Ethiopia. Agriculture and Food Sciences Research, 7(1): 22-27.

History:

Received: 14 November 2019

Revised: 23 December 2019

Accepted: 27 January 2020

Published: 18 March 9090

Licensed: This work is licensed under a Creative Commons

Attribution 3.0 License (cc) EY

Publisher: Asian Online Journal Publishing Group
Acknowledgement: The first Author acknowledges Melkassa Agricultural Research Center (MARC) for providing the test genotypes and for their invaluable support in field trial implementation.

Funding: The authors are grateful to Ethiopian Institute of Agricultural Research (EIAR) for offering financial support.

Competing Interests: The authors declare that they have no conflict of interests.

Transparency: The authors confirm that the manuscript is an honest, accurate, and transparent account of the study was reported; that no vital features of the study have been omitted; and that any discrepancies from the study as planned have been explained.

Ethical: This study follows all ethical practices during writing.

\section{Contents}

1. Introduction

2. Materials and Methods

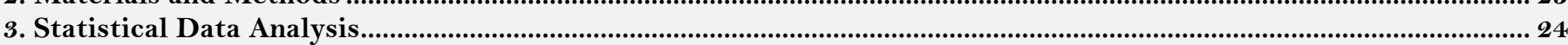

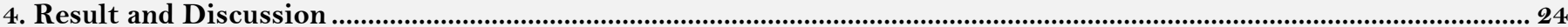

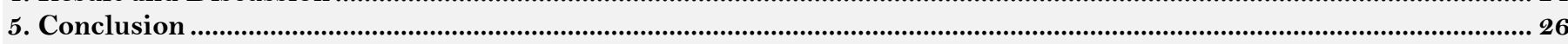

References. 26 


\section{Contribution of this paper to the literature}

The study was conducted at Melkassa Agricultural Research Center (MARC) to assess the genetic variability among 36 tomato genotypes using $6^{*} 6$ simple lattice designs.

\section{Introduction}

Tomato (Lycopersicon esculentum MILL.) is one of the most known and widely grown vegetables in the world. Tomato fruit is traded on the fresh market and used in the processing industry for making ketchup, juice, and soups. It is a valuable component of human diet with high content of important nutrients like $\beta$-carotene, lycopene and vitamin [1].

In Ethiopia, tomato is one of the most popular vegetables produced by small farmers and commercial growers for both local uses as well as processing industries. It has become an important cash crop. Tomato provides employment in production and processing industries [2]. Considering the importance of tomato as one of the beneficial vegetables for both domestic consumption and export markets, it is important to increase its productivity along with desirable attributes through its genetic character [3] The crop is cultivated by small scale farmers under irrigation and rain fed condition and large scale commercial vegetable growers. In Central Rift valley where the study area is conducted the crop is mainly cultivated by small scale farmers and commercial vegetable producers. On the basis of its wide use and expansion potential the need for developing varieties that suite specific agro- ecological conditions and specific end use is clear. Such improvement works, require knowledge on the nature and magnitude of variability in the genotypes [4] and the relative contribution of various component traits to yield [5].

Variability in tomato is expected to be immense as the fruits vary greatly in shape and size [6]. Studies on genetic parameters provide to select and help to develop optimum breeding procedure. Considering all the facts described above the present investigation was undertaken to estimate genetic variability of tomato genotypes.

\section{Materials and Methods}

The experiment was conducted at Melkassa Agricultural Research Center (MARC) in 2017/2018 (at the end of October to February) using furrow irrigation. The site is situated in major snap bean growing belts which is 117 $\mathrm{km}$ South East of Addis Ababa with geographic co-ordinate of $8^{\circ} 24^{\prime} \mathrm{N}$ latitude and $39^{\circ} 12^{\prime} \mathrm{E}$ longitude at an altitude of 1550 m.a.s.l. The mean annual rainfall of the area is $763 \mathrm{~mm}$ and the mean annual maximum and minimum temperature is about $28.6^{\circ} \mathrm{C}$ and $13.8^{\circ} \mathrm{C}$, respectively. The soil texture is dominantly loam and clay loam and is slightly alkaline ranging from 7.4 to $7.6 \mathrm{pH}$ an optimum range for availability of major nutrients [7]. The experimental materials in the present study consisted of thirty six tomato genotypes obtained from Melkassa Agricultural Research Center. Simple lattice design (6x6) was employed where each plot consisted of two rows with length of $4 \mathrm{~m}$ and width $2 \mathrm{~m}$ that makes a total area of $8 \mathrm{~m}^{2}$. The spacing was $100 \mathrm{~cm}$ and $30 \mathrm{~cm}$ between rows and plants respectively. Fertilizer rate of $200 \mathrm{~kg}$ per ha of NPS and $150 \mathrm{~kg}$ per ha of Urea was applied. All other necessary cultural practices were applied to all plots uniformly.

\subsection{Data Collected}

\subsubsection{Data Collected on Plot Basis}

Days to first flowering (days): The number of days from the date of transplanting to the day when the first flower bud opens in a plot.

Days to 50 percent flowering (days): The number of days from the date of transplanting to when about $50 \%$ of the plants produced flowers.

Days to first fruit set (days): The number of days was counted from the date of transplanting to when first fruit appeared in a plot.

\subsubsection{Data Collected on Plant and Fruit Basis}

Plant height (cm): The plant height was measured using measuring tape from ground level to the tip of the plant after 60 days of transplanting and expressed in centimeters and the mean was computed.

Number of branches per plant: Number of branches arising from the main stem above the ground was counted at harvesting on individual plant basis.

Number of flowers per cluster: Three clusters in each plant were taken at random and the number of flowers in each cluster was counted. Then the average number of flowers per cluster was calculated.

Number of Clusters per plant: Fine plants were taken at random and the number of clusters in each plant was counted. Then the average number of cluster per plant was calculated. Harvesting continued for about one month because fruits of different genotypes matured progressively at different dates and over longtime. Fruits were picked on the basis of horticultural maturity, size color and age being determined for the purpose of consumptions as the fruit grew rapidly and soon get beyond the marketable stage frequent picking was done throughout the harvesting period.

Number of fruits per plant: The total number of fruits harvested from the five plants was counted and the average number of fruits per plant was calculated.

Number of fruits per cluster: Three clusters in each plant were taken at random and the number of fruits in each cluster was counted. Then the average number of fruits per cluster was calculated.

Fruit yield per plant: The weight of fruits from each picking was from each experimental plot. Total yield per plant was worked out by adding yield of all harvests and was expressed in gram (g) per plant.

Fruit length $(\mathbf{c m})$ : Average fruit length of five fruits from five plants was measured using Vernier caliper from tip to the base of the fruit and expressed in centimeters.

Fruit diameter $(\mathbf{c m})$ : Average diameter of five fruits from each sampled plants was measured using Venire caliper at the highest bulged portion of the fruit in centimeters. 
Fruit weight (g): Average weight of five fully ripe fruits taken during harvesting was taken using sensitive balance.

Pericarp thickness (mm): It was recorded from five randomly selected fruits at second harvest by cutting the cross section of a fruit and measuring the pericarp thickness using Vernier caliper expressed in centimeter.

Fruit shape index: Ration of fruit length to width were recorded from five randomly selected fruits at second harvest.

pH of tomato fruit: Tomato juice was extracted from red ripe fruits, was determined from extracted juice, by using $\mathrm{pH}$ meter at room temperature.

Total soluble solids content of fruit ( ${ }^{\circ}$ Brix): Brix percentage was measured by Portable Refractometer at room temperature. Single fruit was blend and juice was collected to measure brix.

Juice volume $(\mathbf{m l})$ : Tomato juice was prepared by selecting five typical and red ripe fruits from sample plants and juice was measured in cylinder and expressed in milliliter $(\mathrm{ml})$.

\section{Statistical Data Analysis}

Data were subjected to Analysis of variance as per the procedure for simple lattice design as described by Gomez and Gomez [8] using SAS version 9.2 [9]. Duncan's Multiple Range Test was used for mean separation procedures.

\subsection{Variability Analysis}

\section{A. Estimation of Variance Components}

The phenotypic and genotypic variances were estimated according to the method suggested by Singh and Choudhary [10] as follows:

Environmental variance $\left(\sigma^{2} \mathrm{e}\right), \sigma^{2} \mathrm{e}=\mathrm{MSe}$ (error mean square)

Genotypic Variance $\left(\sigma^{2} \mathrm{~g}\right) \quad \sigma^{2} \mathrm{~g}=\frac{\mathrm{MSg}-\mathrm{MSe}}{\mathrm{r}}$

Phenotypic variance $\left(\sigma^{2} \mathrm{p}\right) \quad \sigma^{2} \mathrm{~g}+\sigma^{2} \mathrm{e} / \mathrm{r}$

Where, $\mathrm{r}=$ number of replication, $\mathrm{MSg}=$ mean square due to genotypes, MSe=mean square of error (Environmental variance)

\section{B. Heritability in Broad Sense}

Broad sense heritability values for all parameters $\left(\mathrm{H}^{2}\right)$ were estimated based on the formula given by Falconer and Mackay [11] as follows:

$$
\mathrm{H}^{2}=\frac{\sigma^{2} \mathrm{~g}}{\sigma^{2} \mathrm{p}} * 100
$$

Where, $\mathrm{H}^{2=}$ heritability in the broad sense, $\sigma^{2} \mathrm{~g}=$ genotypic variance and $\sigma^{2} \mathrm{p}=$ phenotypic variance. Estimated heritability values was classified according to Singh [12] that heritability values greater than $80 \%$ were very high, values from $60-79 \%$ were moderately high, values from $40-59 \%$ were medium and values less than $40 \%$ were low.

\section{Genetic Advance}

The genetic advance expected under selection assuming selection intensity of the superior $5 \%$ of the plants was estimated in accordance with the methods illustrated by Allard [13].

\section{$\mathrm{GA}=\mathrm{K} *\left(\sqrt{ } \sigma_{\mathrm{p}}^{2}\right) * \mathrm{H}^{2}$}

Where, $\mathrm{GA}=$ expected genetic advance, $\mathrm{K}=$ the standardized selection differential at $5 \%$ selection intensity $(\mathrm{K}$ = 2.063), $\sigma^{2} \mathrm{p}=$ is phenotypic standard deviation on mean basis and $\mathrm{H}^{2}=$ heritability in the broad sense.

\section{Genetic Advance as Percent of Means (Gam)}

Genetic advance as percentage over mean was worked as suggested by Johnson, et al. [14]. GAM $=\frac{\text { GA }}{\bar{x}} *$ 10Where, $\mathrm{GA}=$ Genetic advance, $\bar{x}=$ Grand mean;

Genetic advance as percent of mean was categorized as 0-10\% $=$ Low, $10-20 \%=$ Moderate, $>20 \%=$ High

\section{E. Genotypic and Phenotypic Coefficient of Variation}

Genotypic and phenotypic coefficients of variation were estimated according to Burton and Devane [15] based on the estimate of genotypic and phenotypic variance.

Genotypic coefficient of variation $(\mathrm{GCV} \%)=\frac{\sqrt{\sigma 2} \mathrm{~g}}{\bar{x}} * 100$

Phenotypic coefficient of variation $(\mathrm{PCV} \%)=\frac{\sqrt{\sigma 2} \mathrm{p}}{\bar{x}} * 100$

Where, $\mathrm{V}_{\mathrm{g}}=$ Genotypic variance, $\mathrm{V}_{\mathrm{p}}=$ Phenotypic variance, $\bar{x}=$ Grand mean of the character. PCV and GCV were categorized as following: $0-10 \%$ : low, $10-20 \%$ : moderate, $20 \%$ and above high [16].

\section{Result and Discussion}

\subsection{Analysis Variance}

The mean square due to genotypes were highly significant for all traits $(P<0.01)$ except for days to $50 \%$ flowering, plant height, number of branches per plant, number of fruits per cluster and pericarp thickness which were significant at $(P<0.05)$, indicating the presence of sufficient genetic variability in the genotypes and considerable scope for their improvement Table 1. According to Asati, et al. [17] analysis of variance revealed that significant differences among the genotypes for all the traits; Aysh, et al. [18] reported that the highly significant differences observed among the genotypes evaluated indicates existence of a good deal of variability with respect of the characteristics assessed and offers ample chances for the genetic improvement of the tomato germplasm; Meena 
and Bahadur [19] reported that there were significant differences among germplasm for all the traits studies indicating the presence of significant variability in the materials which can be exploited through selection; Shankar Shankar, et al. [20]; Haydar, et al. [21] and Singh, et al. [22] revealed that highly significant differences among the genotypes for all the characters indicating sufficient variability existed in the present material selected for the study and indicating the scope for selection of suitable initial breeding material for crop improvement; Kumar, et al. [23] reported that significant differences among germplasm for all the traits studies indicating the presence of significant variability in the materials which can be exploited through selection.

\subsection{Estimation of Genotypic and Phenotypic Coefficient Variation}

The present result revealed that, higher GCV were recorded for number fruits per plant (25.29607\%), fruit yield per plant $(21.7934 \%)$, average fruit weight $(21.93702 \%)$, fruit shape index $(25.65 \%)$ and juice volume $(23.9115 \%)$. Moderate GCV value were recorded for days to first flowering date (15.76\%), plant height (13.21\%), number branches per plant (13.34\%), number flowers per cluster (16.44), number fruits per cluster $(13.35 \%)$, number clusters per plant (16.68\%), fruit length $(14.18 \%)$ and fruit diameter $(12.67 \%)$. However total soluble solid (8.93\%), pericarp thickness $(8.91 \%), \mathrm{pH}(7.58 \%)$, days to $50 \%$ flowering date $(7.37 \%)$ and days to first fruit set $(5.74 \%)$ had the lowest values. High PCV values were observed in fruit shape index (26.791\%), number of fruits per plant $(26.408 \%)$, juice volume $(25.732 \%)$, average fruit weight $(24.408 \%)$, fruit yield per plant $(22.991 \%)$ and number of clusters per plant (20.207\%). However days to first flowering (18.177\%), number of flowers per plant(17.333\%),number of branches per plant(17.148\%), plant height (15.287\%), fruit length(15.071\%),pericarp thickness(14.085\%),number of fruits per plant(14.978\%), fruit diameter(13.586\%) and total soluble solid(12.092), had moderate values. This indicated the presence of environmental influence on these characters [24].

\subsection{Heritability and Genetic Advance}

Heritability ranged from $(55.22 \%)$ for total soluble solid to $(98.08 \%)$ for $\mathrm{pH}$ and characters such with very high heritability values were obtained for $\mathrm{pH}(98.08 \%)$, fruit shape index (95.65\%), number of fruit per plant $(91.75 \%)$, number of flowers per cluster $(89.38 \%)$, fruit yield per plant $(89 \%)$, fruit length $(88.25 \%)$, fruit diameter $(87.69 \%)$, juice volume $(86.35 \%)$ and average fruit weight $(80.05 \%)$; moderately high heritability values were obtained from number of fruits per cluster $(79.13 \%)$, days to first flowering $(75.15 \%)$, plant height $(74.71 \%)$, days to first fruit set $(71.95 \%)$, number of clusters per plant $(68.09 \%)$ and number of branches per plant (60.53\%); whereas pericarp thickness $(55.14 \%)$ and total soluble solid $(55.22 \%)$ had moderate heritability values Table 2.

\begin{tabular}{|c|c|c|c|c|c|c|c|c|c|c|}
\hline \multirow[b]{2}{*}{$\begin{array}{l}\text { Source of } \\
\text { variation }\end{array}$} & \multirow[b]{2}{*}{ DF } & \multicolumn{9}{|c|}{ Mean squares } \\
\hline & & DFF & D50\%F & DFFS & PLH & NBPL & NFLC & NFC & NCPL & NFPT \\
\hline Replications & 1 & 107.56 & 14.22 & 24.5 & 16.43 & 28.8 & 0.294 & 28.34 & 1.28 & 2105.46 \\
\hline $\begin{array}{l}\text { Block within } \\
\text { Reps(adj) }\end{array}$ & 10 & 80.56 & 11.25 & 4.083 & 31.37 & 3.7 & 0.176 & 0.2383 & 195.85 & 2643.04 \\
\hline \multicolumn{11}{|l|}{ Genotypes } \\
\hline - Un adjusted & 35 & 50.5 & 22.01 & 23.3143 & 125.66 & 4.2521 & 0.6844 & 0.38 & 742.62 & 225.26 \\
\hline - adjusted & 35 & $46.540^{* * *}$ & $19.845^{*}$ & $22.55^{* * *}$ & $120.46^{*}$ & $3.986^{*}$ & $0.63^{* *}$ & $0.34^{*}$ & $21.8^{* *}$ & $312.08 * *$ \\
\hline \multicolumn{11}{|l|}{ Error } \\
\hline -RCB Design & 35 & 10.6 & 22.01 & 4.4 & 30.33 & 2.068 & 0.1419 & 0.17 & 376.04 & 5131.14 \\
\hline -Intra block & 25 & 11.5556 & 6.32 & 4.5 & 29.8 & 1.4211 & 0.1283 & 0.1424 & 7.207 & 24.8811 \\
\hline $\mathrm{CV} \%$ & & 12.84 & 6.27 & 5.07 & 10.87 & 15.24 & 8.01 & 9.69 & 16.15 & 10.725 \\
\hline $\mathrm{R}^{2}$ & & 87.1 & 85 & 88.66 & 86.4 & 85.78 & 89.02 & 92.48 & 83.911 & 95.79 \\
\hline $\begin{array}{l}\text { Efficiency of lattice } \\
\text { over RCBD }\end{array}$ & & 91.34 & 108.65 & 97.32 & 100.11 & 123.77 & 102.66 & 106.94 & 126.27 & 125.03 \\
\hline
\end{tabular}

Note: Where ** = highly significant at $1 \%$, * = significant at $5 \%, \mathrm{DF}=$ Degree of Freedom, DFF $=$ Days to first flowering, D50\%F = Days $50 \%$ flowering, DFFS = Days NFPLT = number fruits/plant, $\mathrm{R}^{2}=$ coefficient of determination.

Table-1. (Continued).

\begin{tabular}{|c|c|c|c|c|c|c|c|c|c|c|}
\hline \multirow[b]{2}{*}{$\begin{array}{l}\text { Source of } \\
\text { variation }\end{array}$} & \multirow[b]{2}{*}{ DF } & \multicolumn{9}{|c|}{ Mean squares } \\
\hline & & FL & FD & AFW & FYPT & PTH & FSI & pH & TSS & JV \\
\hline Replications & 1 & 0.2069 & 0.28 & 715.52 & 67230 & 0.0003 & 0.001 & 0.009 & 2.3112 & 27417 \\
\hline $\begin{array}{l}\text { Block within } \\
\text { Reps(adj) }\end{array}$ & 10 & 0.2777 & 0.1023 & 126.41 & 208112 & 0.0064 & 0.021 & 0.016 & 0.2849 & 6109.51 \\
\hline \multicolumn{11}{|l|}{ Genotypes } \\
\hline - Un adjusted & 35 & 2.215 & 1.07 & 1672.57 & 465169 & 0.014 & 0.24 & 0.0188 & 0.4072 & 58021 \\
\hline - Adjusted & 35 & $2.15^{* * *}$ & $1.16^{* * *}$ & $1609.99 * *$ & $468652^{* *}$ & $0.014^{*}$ & $0.24 * *$ & $0.27 * *$ & $0.42 * *$ & $55723.4 * *$ \\
\hline \multicolumn{11}{|l|}{ Error } \\
\hline -RCB Design & 35 & 0.2563 & 0.1237 & 270.19 & 2024662 & 0.0058 & 0.013 & 0.01735 & 0.2204 & 11853 \\
\hline -Inter block & 25 & 0.2477 & 0.132 & 327.7 & 42303.7 & 0.006 & 0.01 & 0.0047 & 0.1946 & 6917.014 \\
\hline $\mathrm{CV} \%$ & & 7.32 & 6.722 & 15.488 & 10.341 & 10.53 & 7.49 & 1.512 & 11.372 & 13.3 \\
\hline $\mathrm{R}^{2}$ & & 92.85 & 92.13 & 88.07 & 93.84 & 80 & 97.34 & 99.26 & 79.96 & 91.98 \\
\hline $\begin{array}{c}\text { Efficiency of } \\
\text { lattice over } \\
\text { RCBD }\end{array}$ & & 100.36 & 93.5321 & 82.4505 & 103.53 & 100.6 & 116.47 & 98.082 & 103.86 & 83.7648 \\
\hline
\end{tabular}

fruit yield/ plant, $\mathrm{PTH}=$ pericarp thickness, $\mathrm{FSI}=$ fruit shape index, $\mathrm{p}^{\mathrm{H}}=$ power of hydrogen, $\mathrm{TSS}=$ total soluble solid, $\mathrm{JV}=$ juice volume, $\mathrm{R}^{2}=$ coefficient of determination. 
High heritability along with high genetic advance as percent of the mean are exhibited by number of fruits per plant, number of flowers per cluster, fruit yield per plant, fruit length, fruit diameter, average fruit weight, number of fruits per cluster, days to first flowering, plant height, fruit shape index and juice volume; high heritability along with moderate genetic advance as percent of the mean are exhibited by days to $50 \%$ flowering, days to first fruit set and power of hydrogen; and medium heritability along with moderate genetic advance as percent of the mean are exhibited by total soluble solid and pericarp thickness. High estimate of heritability may be the result of the diverse nature of the genotypes included in the study Shushay, et al. [25]. Sunil, et al. [26] reported that high heritability coupled with high genetic advance were noticed for number of fruits per plant, average fruit weight and fruit yield per plant in tomato.

\begin{tabular}{|c|c|c|c|c|c|c|c|c|c|c|}
\hline Traits & Range & Mean \pm Std & $\mathbf{S g}^{2}$ & $\mathbf{S}_{\mathrm{p}}{ }^{2}$ & $\mathbf{S e}^{2}$ & PCV\% & GCV\% & $\mathbf{H}^{2}$ & GA & GAM\% \\
\hline DFF & $40.5-17$ & $26.5277 \pm 5.62$ & 17.47 & 23.25 & 11.56 & 18.177 & 15.76 & 75.15 & 7.47 & 28.18 \\
\hline $\mathrm{D} 50 \% \mathrm{~F}$ & $47.5-35$ & $40.083 \pm 3.86$ & 8.73 & 11.89 & 6.32 & 8.603 & 7.37 & 73.42 & 5.22 & 13.03 \\
\hline DFFS & $49-36$ & $41.833 \pm 3.74$ & 5.77 & 8.02 & 4.50 & 6.770 & 5.74 & 71.95 & 4.20 & 10.05 \\
\hline PLH & $77.6-40$ & $50.211 \pm 8.78$ & 44.02 & 58.92 & 29.80 & 15.287 & 13.21 & 74.71 & 11.83 & 23.56 \\
\hline NBPL & $\begin{array}{c}12.83- \\
5.7\end{array}$ & $7.824 \pm 1.88$ & 1.09 & 1.80 & 1.42 & 17.148 & 13.34 & 60.54 & 1.68 & 21.42 \\
\hline NFLC & $6.4-3.4$ & $4.469 \pm 0.64$ & 0.54 & 0.60 & 0.13 & 17.333 & 16.44 & 89.38 & 1.43 & 32.07 \\
\hline $\mathrm{NFC}$ & $\begin{array}{c}4.831- \\
2.93 \\
\end{array}$ & $3.893 \pm 0.82$ & 0.27 & 0.34 & 0.14 & 14.978 & 13.35 & 79.13 & 0.95 & 24.49 \\
\hline NCPL & $23.4-11$ & $16.628 \pm 3.97$ & 7.69 & 11.29 & 7.20 & 20.207 & 16.68 & 68.09 & 4.72 & 28.39 \\
\hline NFPLT & $\begin{array}{c}69.8- \\
28.1 \\
\end{array}$ & $\begin{array}{c}46.510 \pm \\
14.59 \\
\end{array}$ & 138.42 & 150.86 & 24.88 & 26.408 & 25.30 & 91.75 & 23.25 & 49.99 \\
\hline FL & $\begin{array}{c}9.10- \\
4.9 \\
\end{array}$ & $6.799 \pm 1.11$ & 0.93 & 1.05 & 0.25 & 15.071 & 14.18 & 88.25 & 1.87 & 27.49 \\
\hline FD & $\begin{array}{c}6.879- \\
3.35 \\
\end{array}$ & $5.409 \pm 0.77$ & 0.47 & 0.54 & 0.13 & 13.586 & 12.67 & 87.69 & 1.32 & 24.48 \\
\hline AFW & $\begin{array}{c}193.5- \\
65.8 \\
\end{array}$ & $\begin{array}{c}116.881 \pm \\
31.11 \\
\end{array}$ & 657.42 & 821.27 & 327.70 & 24.519 & 21.94 & 80.05 & 47.33 & 40.49 \\
\hline FYPLT & $\begin{array}{l}3086- \\
1407.9 \\
\end{array}$ & $\begin{array}{c}1988.880 \pm \\
574.51 \\
\end{array}$ & 187942.10 & 209094.00 & 42303.70 & 22.991 & 21.80 & 89.88 & 847.92 & 42.63 \\
\hline PTH & $\begin{array}{c}0.849- \\
0.498 \\
\end{array}$ & $0.71 \pm 0.09$ & 0.00571 & 0.01 & 0.01 & 14.085 & 8.91 & 57.14 & 0.10 & 13.89 \\
\hline FSI & $\begin{array}{c}2.7082- \\
0.8592 \\
\end{array}$ & $1.293 \pm 0.35$ & 0.11 & 0.12 & 0.01 & 26.791 & 25.65 & 95.65 & 0.67 & 51.75 \\
\hline $\mathrm{Ph}$ & $\begin{array}{l}4.44- \\
3.995 \\
\end{array}$ & $4.570 \pm 0.13$ & 0.12 & 0.12 & 0.00 & 7.580 & 7.58 & 98.08 & 0.71 & 15.49 \\
\hline TSS & $5-2.6$ & $3.879 \pm 0.58$ & 0.12 & 0.22 & 0.19 & 12.092 & 8.93 & 55.22 & 0.53 & 13.69 \\
\hline JV & $\begin{array}{c}1030- \\
265\end{array}$ & $\begin{array}{c}618.681 \pm \\
186.63\end{array}$ & 21885.00 & 25343.55 & 6917.01 & 25.732 & 23.91 & 86.35 & 283.60 & 45.84 \\
\hline
\end{tabular}

Note: Where, Std = Standard Deviation, DFF = Days to first flowering, D50\%F = Days to $50 \%$ flowering, DFS $=$ Days to fruit set, PLH $=$ Plant height, NBPL $=$ Number of
branches per plant, $\mathrm{NFLC}=$ number flowers/cluster, $\mathrm{NFC}=$ number fruits/cluster, $\mathrm{NCPL}=$ number of clusters $/$ plant, $\mathrm{NFPLT}=$ number fruits $/$ plant, $\mathrm{FL}=$ fruit length, $\mathrm{FD}$ $=$ fruit diameter, AFW $=$ average fruit weight, FYPLT $=$ fruit yield $/$ plant, PTH $=$ pericarp thickness, FSI $=$ fruit shape index, $\mathrm{pH}=$ power of hydrogen, TSS $=$ total soluble solid, $\mathrm{JV}=$ juice volume.

\section{Conclusion}

The present investigations revealed the presence of good variability among genotypes with respect to different traits considered. Thus there is an opportunity to improve tomato through direct selection or hybridization that involves crossing of different genotypes.

\section{References}

[1] V. Bergougnoux, "The history of tomato: From domestication to biopharming," Biotechnology Advances, vol. 32, pp. 170-189, 2014.Available at: https://doi.org/10.1016/j.biotechadv.2013.11.003.

[2] J. Haji, "Economic efficiency and Marketing performance of vegetable production in the Eastern and central parts of Ethiopia," Ph.D Dessertation, Swedish University of Agricultural Sciences, 2008.

[3] D. Lemma, "Agronomic studies on tomato and capsicum. Vitamin C content of horticultural crops," Post-Harvest Biology and Technology, vol. 20, pp. 207-220, 2002.

[4] J. Dudley and R. Moll, "Interpretation and use of estimates of heritability and genetic variances in plant breeding 1," Crop Science, vol. 9, pp. 257-262, 1969.Available at: https://doi.org/10.2135/cropsci1969.0011183x000900030001x.

[5] B. D. Singh, Plant breeding: Principles and methods. Ludhiana, New Delhi: Kalyani Publishers, 1993.

[6] N. V. Bhardwaj and M. K. Sharma, "Genetic parameters and character association in tomato," Bangladesh Journal of Agricultural Research, vol. 30, pp. 49-56, 2005.

[7] T. Mesfine, G. Abebe, and A.-R. M. Al-Tawaha, "Effect of reduced tillage and crop residue ground cover on yield and water use efficiency of sorghum (Sorghum bicolor (L.) Moench) under semi-arid conditions of Ethiopia," World Journal of Agricultural Sciences, vol. 1, pp. 152-160, 2005.

[8] K. A. Gomez and A. A. Gomez, Statistical procedures for agricultural research, 2nd ed. New York: John Wiley and Sons, 1984. SAS Institute Inc, Statistical analysis software version 9.2. Cary, NC, USA: SAS Institute Inc, 2008.

P. K. Singh and R. D. Choudhary, Biometrical methods in quantitative genetic analysis. New Delhi: Kalyani Publishers, 1977.

D. S. Falconer and T. F. C. Mackay, Hardy-Weinberg equilibrium. Introduction to quantitative genetics, 4th ed. Harlow, Essex, UK: Addison Wesley Longman, 1996.

[12] B. D. Singh, Plant breeding: Principles and methods, 6th ed. New Delhi, India: Kalyani Publishers, 2001.

[13] R. W. Allard, Principles of plant breeding. New York: John Willey and Sons. Inc, 1960.

[14] H. W. Johnson, H. Robinson, and R. Comstock, "Estimates of genetic and environmental variability in soybeans 1," Agronomy Journal, vol. 47, pp. 314-318, 1955.Available at: https://doi.org/10.2134/agronj 1955.00021962004700070009x.

[15] G. W. Burton and d. E. Devane, "Estimating heritability in tall fescue (Festuca arundinacea) from replicated clonal material 1," Agronomy Journal, vol. 45, pp. 478-481, 1953.Available at: https://doi.org/10.2134/agronj1953.00021962004500100005x.

[16] S. Sivasubramanian and N. Menon, "Heterosis and inbreeding depression in rice," Madras Agricultural Journal, vol. 60, pp. 11391144, 1973. 
[17] B. Asati, N. Rai, and A. Singh, "Genetic parameters study for yield and quality traits in tomato," Asian Journal of Horticulture, vol. 3, pp. 222-225, 2008.

[18] F. Aysh, H. Kutma, and A. A. Zouabi, "Genetic variation, heritability and interrelationships of some important characteristics in Syrian tomato landraces (Solanum lycopersicum L.)," Academia Arena, vol. 4, pp. 1-5, 2012.

[19] O. P. Meena and V. Bahadur, "Genetic association analysis for fruit yield and its contributing traits of indeterminate tomato (Solanum lycopersicum L.) germplasm under open field condition," Journal of Agricultural Science, vol. 7, pp. 148-163, 2015.Available at: https://doi.org/10.5539/jas.v7n3p148.

[20] A. Shankar, R. Reddy, M. Sujatha, and M. Pratap, "Genetic variability studies in F1 generation of tomato (Solanum lycopersicon L.)," IOSR Journal of Agriculture and Veterinary Science, vol. 4, pp. 31-34, 2013.Available at: https://doi.org/10.9790/2380-0453134.

[21] A. Haydar, M. Mandal, M. Ahmed, M. Hannan, R. Karim, M. Razvy, U. Roy, and M. Salahin, "Studies on genetic variability and interrelationship among the different traits in tomato (Lycopersicon esculentum Mill.)," Middle-East Journal of Scientific Research, vol. 2, pp. 139-142, 2007.

[22] N. Singh, C. Ram, C. Deo, G. Yadav, and D. P. Singh, "Genetic variability, heritability and genetic advance in tomato (Solanum lycopersicum L.)," Plant Archives, vol. 15, pp. 705-709, 2015.

[23] S. Kumar, V. Vijayakumar Rathod, J. Bommesh, S. Vijeth, and K. Muthaiah, "Genetic variability in tomato (Solanum Lycopersicum L.)," Journal Environment Biological Science, vol. 30, pp. 47-51, 2016.

[24] J. P. Sharma, A. K. Singh, and S. Kumar, "Identification of traits for ideotype selection in tomato (Lycopercon esculentum Mill.)," Mysore Journal of Agricultural Science, vol. 43, pp. 222-226, 2009.

[25] C. Shushay, B. Derbew, and A. Fetien, "Performance evaluation and path analysis studies in tomato (Solanum lycopersicon L) genotpes under Humera, Northern Ethiopia condition," World Journal of Agricultural Research, vol. 2, pp. 267-271, 2014a.

[26] M. K. Sunil, V. Rathod, J. C. Bommesh, S. Vijeth, and K. K. Muthaiah, "Genetic variability in tomato (Solanum Lycopersicum L.)," Journal of Environmental Biology-Science, vol. 30, pp. 47-51, 2016. 